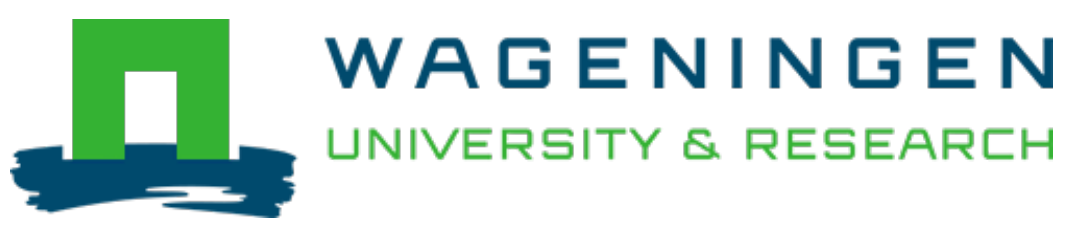

\title{
Genetic differentiation and trade among populations of Peach Palm (Bactris gasipaes Kunth) in the Peruvian Amazon - implications for genetic resource management
}

Theoretical and Applied Genetics

Adin, A.; Weber, J.C.; Sotelo Montes, C.; Vidaurre, H.; Vosman, B.J. et al

https://doi.org/10.1007/s00122-003-1581-9

This article is made publicly available in the institutional repository of Wageningen University and Research, under the terms of article $25 \mathrm{fa}$ of the Dutch Copyright Act, also known as the Amendment Taverne. This has been done with explicit consent by the author.

Article 25 fa states that the author of a short scientific work funded either wholly or partially by Dutch public funds is entitled to make that work publicly available for no consideration following a reasonable period of time after the work was first published, provided that clear reference is made to the source of the first publication of the work.

This publication is distributed under The Association of Universities in the Netherlands (VSNU) 'Article $25 \mathrm{fa}$ implementation' project. In this project research outputs of researchers employed by Dutch Universities that comply with the legal requirements of Article 25fa of the Dutch Copyright Act are distributed online and free of cost or other barriers in institutional repositories. Research outputs are distributed six months after their first online publication in the original published version and with proper attribution to the source of the original publication.

You are permitted to download and use the publication for personal purposes. All rights remain with the author(s) and / or copyright owner(s) of this work. Any use of the publication or parts of it other than authorised under article $25 \mathrm{fa}$ of the Dutch Copyright act is prohibited. Wageningen University \& Research and the author(s) of this publication shall not be held responsible or liable for any damages resulting from your (re)use of this publication.

For questions regarding the public availability of this article please contact openscience.library@,wur.nl 
A. Adin • J. C. Weber • C. Sotelo Montes •

H. Vidaurre • B. Vosman • M. J. M. Smulders

\section{Genetic differentiation and trade among populations of peach palm (Bactris gasipaes Kunth) in the Peruvian Amazon- implications for genetic resource management}

Received: 17 November 2003 / Accepted: 12 December 2003 / Published online: 18 February 2004

(C) Springer-Verlag 2004

\begin{abstract}
Peach palm (Bactris gasipaes Kunth) is cultivated for fruit and 'heart of palm', and is an important component of agroforestry systems in the Peruvian Amazon. In this study, AFLP was used to compare genetic diversity among domesticated populations along the Paranapura and Cuiparillo rivers, which are managed by indigenous and colonist farming communities, respectively. Gene diversity was 0.2629 for the populations in indigenous communities and 0.2534 in colonist communities. Genetic differentiation among populations $\left(G_{\mathrm{st}}\right)$ was $0.0377-0.0416(P<0.01)$ among populations along both rivers. There was no relation between genetic differentiation and the geographical location of populations along the rivers. Since natural seed dispersal by birds and rodents is thought to occur only across relatively short distances (100-200 m), it is likely that exchange of material by farmers and commercial traders is responsible for most of the 'long-distance' (over more than $20 \mathrm{~km}$ ) gene flow among populations along the two rivers studied. This exchange of material may be important to
\end{abstract}

Communicated by H.F. Linskens

A. Adin · B. Vosman · M. J. M. Smulders (

Plant Research International, Wageningen UR,

P.O. Box 16, 6700 AA Wageningen, The Netherlands

e-mail: rene.smulders@wur.nl

J. C. Weber · C. Sotelo Montes · H. Vidaurre

International Centre for Research in Agroforestry (ICRAF),

Pucallpa, Peru

Present address:

A. Adin, East-West Seed Company,

41181 Purwakarta, Indonesia

Present address:

J. C. Weber, 2224 NW 11th Street, Corvallis, OR 97330, USA

Present address:

C. Sotelo Montes, Department of Wood and Forest Sciences,

Laval University, Quebec, G1K 7P4, Canada

Present address:

H. Vidaurre, Trópicos, Pucallpa, Peru counteract the effects of selection as well as genetic drift in small groups of trees in farmers' fields, much as in a metapopulation, and may account for the weak genetic differentiation between the two rivers $\left(G_{\mathrm{st}}=0.0249\right.$, $P<0.01)$. A comparison with samples from other landraces in Peru and Brazil showed the existence of an isolation-by-distance structure up to $3,000 \mathrm{~km}$, consistent with gene flow on a regional scale, likely mediated by trade in the Amazon Basin. Results are discussed with regard to practical implications for the management of genetic resources with farming communities.

Electronic Supplementary Material Supplementary material is available in the online version of this article at http://dx.doi.org/10.1007/s00122-003-1581-9

\section{Introduction}

Peach palm, Bactris gasipaes Kunth, was an essential food crop for many pre-Columbian Amerindian communities in the lowland, humid Neotropics, especially in western Amazonia. Today, peach palm, also known as pijuayo (Peru), pejibaye (Costa Rica) or pupunha (Brazil), is cultivated by both indigenous and nonindigenous communities for two commercially valuable products: fruit and 'heart of palm'. The nutritious fruit can be consumed after cooking or processed into a variety of products, including flour for infant formula and baked goods, cooking oil and animal feed (Clement and MoraUrpí 1987; Mora-Urpí et al. 1997). The gourmet heart of palm has potential in the international export market (Villachica 1996; Mora-Urpí and Echeverría 1999). Farmers in the Peruvian Amazon rank peach palm as a priority species for agroforestry (Sotelo Montes and Weber 1997).

Domesticated peach palm consists of a diverse complex of landraces separate from the wild ancestor species (defined as var. chichagui; Clement 1988; Mora-Urpi et al. 1993, 1997; Rodrigues et al. 2003). Sixteen landraces 
have been characterised in the Amazon Basin and Central America, based upon morphological characteristics such as the size and shape of fruits and seeds, and abundance of spines on the stems. Rojas-Vargas et al. (1999) and Miranda (unpublished data) were the first to use isozymes to analyse genetic diversity in peach palm, and Clement et al. (1997) used isozymes to examine relations among progenies and populations of spineless peach palm. Sousa et al. (2001) used RAPDs and Clement et al. (2002) used AFLPs to evaluate relationships among three Brazilian landraces. Rodrigues et al. (2003) validated the morphologically defined landraces in Central America and Amazonia using RAPDs and also suggested that the effective size of peach palm populations was relatively high in Brazil, at least at the level of landraces.

Each landrace consists as a number of 'populations', usually (for convenience) named after municipalities or communities. In this paper, we follow this definition. Within each population, there may be numerous small sub-populations of 10-50 palms in farmers' fields and in areas that were once cultivated and then abandoned, although palms in these abandoned areas tend to disappear as the forest returns (Clement 1990). The plant is pollinated mainly by small, curculionid insects (in the Amazon Basin by several species of Phyllotrox), by gravity and by wind to nearby trees (Mora-Urpí and Solís 1980; Mora-Urpí et al. 1997). The pollinators are thought to have a flight range of only $100-200 \mathrm{~m}$ between palms, and the pollen they carry has a short viability period (Miranda and Clement 1990). As a consequence, gene flow through pollen between peach palm individuals and populations, which often occur scattered across an area, may be quite limited and local. Peach palm is predominantly allogamous, having separate pistilate and staminate flowers and protogynous development. Self-fertilisation occurs, however, and there is considerable variation in self-fertility (Clement and Arkcoll 1984). Patterns of seed dispersal produced by wild animals have not been investigated, but the dispersal distance is thought to be limited. Given these conditions, effective size of breeding populations might be small, and in the absence of other processes the populations in different communities and the sub-populations in farmers' fields may become genetically differentiated.

Human activities have significant effects on many domesticated plant species, and this may also be true for peach palm. The process of domestication and selection tends to decrease the genetic variation of crop species' populations (Tanksley and McCouch 1997; Weber et al. 1997; Ajmone-Marsan et al. 2002). On the other hand, farmers also collect seed from selected palms on neighbouring farms and select fruits in the local markets for planting on their farms (Weber et al. 1997), and this may counteract genetic erosion on farm. Louette (2000) found in Mexico that farmers were constantly looking for new types of maize in neighbouring fields as well as on local markets and in other villages and were testing them next to 'established' landraces. The Mexican landraces did not suffer from genetic erosion, and in the authors' opinion, the trafficking of potential useful genotypes produces the gene flow that is responsible and necessary for the restoration of diversity in seed lots subjected to genetic drift. This process resembles, in its genetic effects, migration within a meta-population (Louette 2000). If the genotypes were drawn from several pools, this process would also prevent an isolation-by-distance model (Giles and Goudet 1997). We do not know to what extent farmers' practices lead to a reduction or maintenance of genetic diversity in peach palm, or whether the practices (and the genetic consequences) vary among ethnic groups (which is a relevant issue, since the Peruvian Amazon is a patchwork of ethnic groups). As a consequence, it is difficult to implement a conservation-through-use approach for peach palm.

For a systematic study of genetic diversity in peach palm on a fine scale, i.e. among palms in farmers' fields and among groups of farmers' fields in communities that make up a landrace (Louette 2000), we focussed on populations of the Pampa Hermosa landrace along two rivers in the Peruvian Amazon in the area near the city of Yurimaguas. We employed AFLP to answer three questions:

1. How much genetic diversity is present within and among populations of peach palm?

2. Is there a difference between two groups of populations, one group managed by indigenous farming communities along the Paranapura River and the other managed by non-indigenous farming communities along the Cuiparillo River?

3 . Is there an isolation-by-distance type of genetic structure as a result of local exchange of genetic material?

For comparison, we included a few samples taken from populations of different landraces in Peru and Brazil. The results are discussed with regard to practical implications for the management of genetic resources within farming communities.

\section{Materials and methods}

Sample collection

Seeds were collected from peach palm in two river systems in the Peruvian Amazon (see Fig. 1 for collection region, Table 1 for geographic coordinates of peach palm populations). Peach palm in this region has been classified as the Pampa Hermosa landrace (Mora-Urpí et al. 1993). Seed collections were conducted in four farming communities along the Cuiparillo River in 1997 and in 12 farming communities along the Paranapura River and associated tributaries in 1999. Farmers along the Paranapura River belong to an indigenous ethnic group (Chayahuita), while those along the Cuiparillo River are non-indigenous in origin (referred to below as 'colonist'). In all cases, farmers selected their preferred peach palm based primarily on fruit characteristics (such as oil and starch content, texture and size). Although this is not a random sample of the palms present in these communities, we believe it is a representative sample of the next generation, since farmers select during every generation cycle, and selection is an essential activity which maintains the (phenotypic) identity of a landrace (Louette 

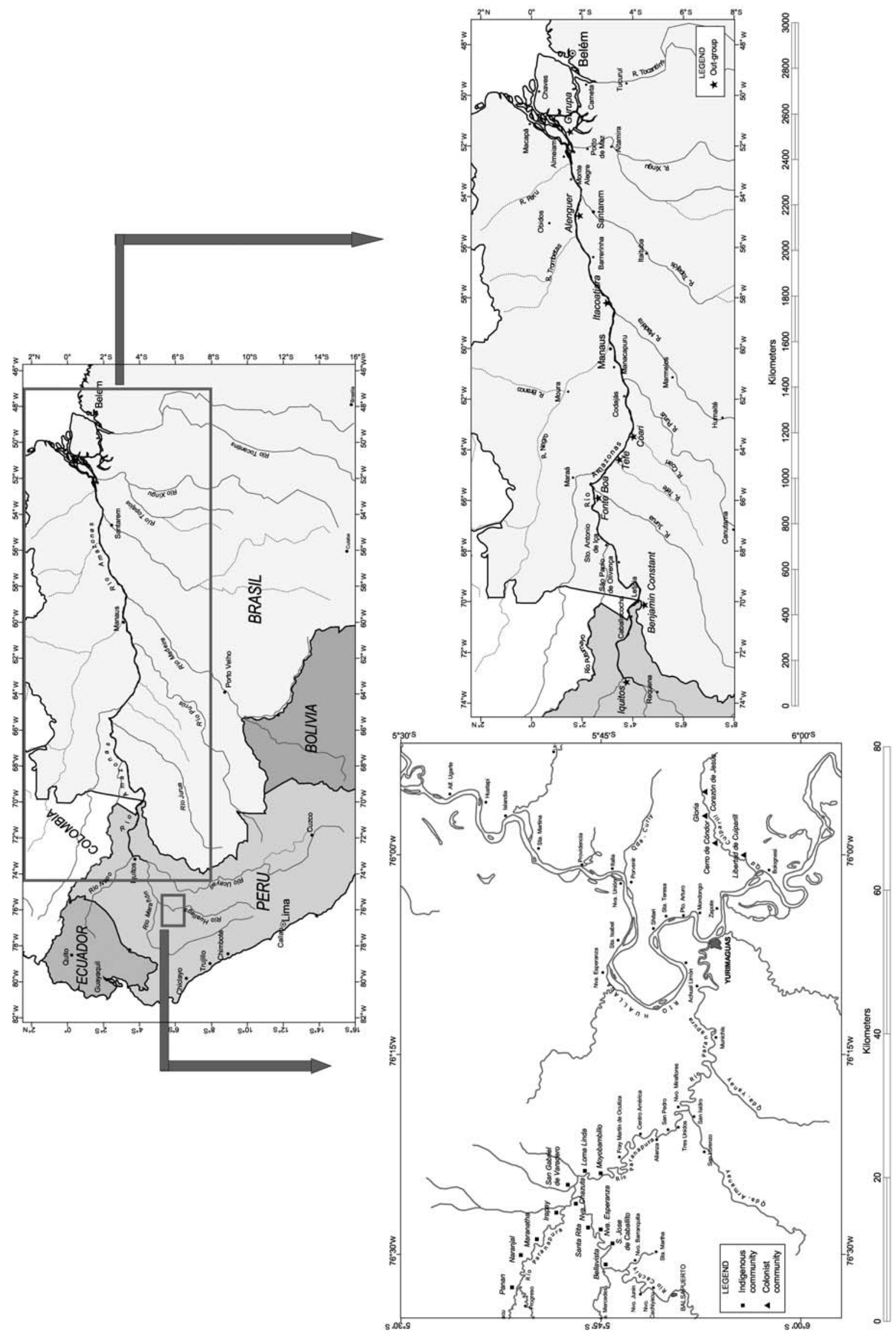

Fig. 1 Study area and location of populations sampled 
Table 1 Location of peach palm populations collected in colonist and indigenous communities in Peru, and other land races in Peru and Brazil

\begin{tabular}{|c|c|c|c|c|c|}
\hline \multirow[t]{3}{*}{ Group } & \multirow[t]{3}{*}{ Region } & \multirow[t]{3}{*}{ Name of population $^{\mathrm{a}}$} & \multirow[t]{3}{*}{ Code $^{b}$} & \multirow{2}{*}{$\frac{\text { Population }}{\text { latitude }^{c}}$} & \multirow{2}{*}{$\frac{\text { Population }}{\text { longitude }^{c}}$} \\
\hline & & & & & \\
\hline & & & & $\left({ }^{\circ} \mathrm{S}\right)$ & $\left({ }^{\circ} \mathrm{W}\right)$ \\
\hline \multirow{4}{*}{$\begin{array}{l}\text { Colonist } \\
\text { Communities }\end{array}$} & \multirow{4}{*}{$\begin{array}{l}\text { Cuiparillo River, } \\
\text { Peru }\end{array}$} & Corazón de Jesús & Col1 & $5^{\circ} 53^{\prime}$ & $75^{\circ} 55^{\prime}$ \\
\hline & & Gloria & Col2 & $5^{\circ} 53^{\prime}$ & $75^{\circ} 57^{\prime}$ \\
\hline & & Cerro de Cóndor & Col3 & $5^{\circ} 54^{\prime}$ & $75^{\circ} 59^{\prime}$ \\
\hline & & Libertad de Cuiparillo & Col4 & $5^{\circ} 54^{\prime}$ & $76^{\circ} 00^{\prime}$ \\
\hline \multirow{12}{*}{$\begin{array}{l}\text { Indigenous } \\
\text { Communities }\end{array}$} & \multirow{12}{*}{$\begin{array}{l}\text { Paranapura River, } \\
\text { Peru }\end{array}$} & Panan & Indi1 & $5^{\circ} 40^{\prime}$ & $76^{\circ} 29^{\prime}$ \\
\hline & & Naranjal & Indi2 & $5^{\circ} 39^{\prime}$ & $76^{\circ} 30^{\prime}$ \\
\hline & & Maranatha & Indi3 & $5^{\circ} 40^{\prime}$ & $76^{\circ} 29^{\prime}$ \\
\hline & & Irapay & Indi4 & $5^{\circ} 42^{\prime}$ & $76^{\circ} 27^{\prime}$ \\
\hline & & Bellavista & Indi5 & $5^{\circ} 46^{\prime}$ & $76^{\circ} 31^{\prime}$ \\
\hline & & San Jose de Caballito & Indi6 & $5^{\circ} 45^{\prime}$ & $76^{\circ} 30^{\prime}$ \\
\hline & & Nva. Esperanza & Indi7 & $5^{\circ} 45^{\prime}$ & $76^{\circ} 29^{\prime}$ \\
\hline & & Nva. Chazuta & Indi8 & $5^{\circ} 42^{\prime}$ & $76^{\circ} 28^{\prime}$ \\
\hline & & San Gabriel de Varadero & Indi9 & $5^{\circ} 42^{\prime}$ & $76^{\circ} 25^{\prime}$ \\
\hline & & Loma Linda & Indi10 & $5^{\circ} 44^{\prime}$ & $76^{\circ} 24^{\prime}$ \\
\hline & & Moyobambillo & Indi11 & $5^{\circ} 45^{\prime}$ & $76^{\circ} 24^{\prime}$ \\
\hline & & Santa Rita & Indi12 & $5^{\circ} 44^{\prime}$ & $76^{\circ} 29^{\prime}$ \\
\hline \multirow{8}{*}{$\begin{array}{l}\text { Other land } \\
\text { races }\end{array}$} & Loreto, Peru & Iquitos & Put1 & $3^{\circ} 55^{\prime}$ & $73^{\circ} 11^{\prime}$ \\
\hline & Amazonas, Brazil & Benjamin Constant & Put2 & $4^{\circ} 22^{\prime}$ & $70^{\circ} 22^{\prime}$ \\
\hline & Amazonas, Brazil & Fonte Boa & Sol3 & $2^{\circ} 38^{\prime}$ & $65^{\circ} 55^{\prime}$ \\
\hline & Amazonas, Brazil & Tefé & Sol4 & $3^{\circ} 22^{\prime}$ & $64^{\circ} 44^{\prime}$ \\
\hline & Amazonas, Brazil & Coari & Sol5 & $4^{\circ} 8^{\prime}$ & $63^{\circ} 18^{\prime}$ \\
\hline & Amazonas, Brazil & Itacoatiara & Par6 & $3^{\circ} 8^{\prime}$ & $58^{\circ} 30^{\prime}$ \\
\hline & Para, Brazil & Alenquer & Par7 & $1^{\circ} 57^{\prime}$ & $54^{\circ} 46^{\prime}$ \\
\hline & Para, Brazil & Gurupá & Par8 & $1^{\circ} 27^{\prime}$ & $51^{\circ} 35^{\prime}$ \\
\hline
\end{tabular}

a Populations are named after towns located nearby. The locations of these towns are shown in Fig. 1. The latitude and longitude of the populations sampled do not correspond exactly with the latitude and longitude of these towns

${ }^{\mathrm{b}} \mathrm{Col}$ Colonist communities along Cuiparillo River, Indi indigenous communities along Paranapura River (both from the Pampa Hermosa landrace), Put Putumayo landrace, Sol Solimões landrace in western Brazil, Par Pará landrace in eastern Brazil

${ }^{\mathrm{c}}$ Mean latitude and longitude of indigenous and colonist populations are calculated from latitude and longitude of all individual palms collected in that population. For out-group populations, latitude and longitude are based on the location of the town used to name the population.
2000). Phenotypic characteristics and geographic location of these selected plants were recorded. In total, 402 palms were thus identified and sampled-100 in the non-indigenous farming communities and 302 in the indigenous communities (Table 1). Seedlings from these plants were grown in a nursery and planted in progeny tests in two locations (Huallaga and Aguaytía watersheds) 1 year after the seed collections. Tissue samples were collected from these seedlings, one for each of the selected palms, in December 2001. For each sample, $25 \mathrm{~cm}^{2}$ of leaf tissue was taken from young basal offshoots. Tissue samples were sealed individually in airtight bags filled with a silica desiccant.

In addition, for comparison, leaf tissue samples were collected from one seedling of each of 39 mother plants representing seven populations in Brazil and one population in Peru (Fig. 1). These 39 plants were sampled in a germplasm bank (Instituto Nacional de Investigación Agraria, Yurimaguas, Peru) in May 2002. The germplasm bank was established in the 1980s following an extensive seed collection in Amazonia; the exact geographic location of the 39 mother plants was not recorded during the seed collection, but all were identified to municipality. These 'landrace' samples probably represent three different landraces (Mora-Urpí et al. 1993): the Putumayo landrace in Peru and western Brazil, the Pará landrace in eastern Brazil and the Solimões landrace in between (Table 1). Recent research using molecular markers suggests that the Solimões landrace may not be a distinct landrace (Sousa et al. 2001; Clement et al. 2002; Rodrigues et al. 2003), although Iriarte-Martel et al. (2003) have questioned this based on a new morphometric analysis of these three landraces. Mora-Urpí and Clement (1988) proposed that Iquitos may be a hybrid population with Putumayo, Pampa Hermosa and Tigre.

\section{AFLP protocol}

For DNA extraction, a small piece $\left(1 \mathrm{~cm}^{2}\right)$ of dried green leaf tissue was ground with four glass pearls in a Retch shaking mill, followed by DNA extraction according to Fulton et al. (1995). The AFLP method (Savelkoul et al. 1999) was performed essentially as described by Vos et al. (1995) with some modifications (Arens et al. 1998). Approximately 80 EcoRI/MseI primer combinations were tested on four samples. Suitable combinations were selected based on the number of unambiguously scorable polymorphic bands. Finally, two primer combinations were selected for analysis: EcoRI-AAC/MseI-CCC (78 polymorphic bands) and EcoR1-ACA/ MseI-CTG (66 polymorphic bands).

\section{Data analysis}

Presence (1) or absence (0) of each polymorphic band was scored for all genotypes. AFLP-SURV version 1.0 (Vekemans et al. 2002) was used to calculate gene diversity statistics and estimate significance of $F_{\text {st }}$ estimates. Gene flow was estimated assuming $N_{\mathrm{m}}=\left(1 / F_{\mathrm{st}}-1\right) / 4$ (Whitlock and McCauley 1999). One thousand distance matrices were used as input into Neighbour and Compare from Phylip (Phylogeny Inference Package) version 3.573c (Felsenstein 1989) to infer bootstrap confidence on the dendrogram tree. Principal coordinate analysis (PCO) was carried out based on the similarity matrix using GENSTAT (5th edition, release 4.2, Lawes Agricultural Trust, VSN International). IBD (Isolation By Distance, version 1.3) (Bohonak 2002) was used to analyse for presence of isolation by distance. Default settings were used, unless described otherwise. 


\section{Results}

Genetic diversity within populations and landraces

A total of 203 progeny plants were analysed from 16 peach palm populations of the Pampa Hermosa landrace in Peru (Table 1) -58 plants from four populations managed by farmers in the colonist communities along the Cuiparillo River and 145 plants from 12 populations managed by farmers in the indigenous communities along the Paranapura River and associated tributaries (Fig. 1). A further 37 plants were analysed from three other landraces to provide a comparison of genetic diversity (Fig. 1). A total of 203 AFLP bands were scored, of which 144 $(70.9 \%)$ were polymorphic. Eight fragments were unique for the Pampa Hermosa landrace, and eight other fragments were uniquely found in the samples from the three other landraces [of which four in Solimões (Sol) and Pará (Par) and one in Pará only], which is noteworthy, considering the small number of samples analysed for these landraces.

The number of polymorphic loci varied directly with population size (Table 2), but the correlation between sample size and number of polymorphic loci (not shown) was always comparable to those of the Paranapura River populations sampled, except for the Pará samples, which contained much less polymorphic fragments than expected. For the two river systems analysed, the average value per population was comparable- $69.6 \%$ for populations from colonist communities along the Cuiparillo river, $66.3 \%$ for populations from indigenous communities along the Paranapura.

The populations managed by indigenous communities along the Paranapura River had marginally higher gene diversity levels $\left(H_{\mathrm{j}}\right.$ from 0.235 to 0.271 , overall 0.2519 ) than colonists' populations along the Cuiparillo River (from 0.228 to 0.265 , overall 0.2439 , Table 2). All populations together are an approximation of the landrace Pampa Hermosa, and for this landrace the gene diversity was estimated at $\sim 0.2480$. This was marginally higher than in the other three landraces $(0.2373)$, but this may well reflect the fact that the number of samples was considerably greater for the Pampa Hermosa landrace.

Among the samples from other landraces, the populations from the Pará landrace in eastern Brazil (Itacoatiara, Alenquer, Gurupá) had very low diversity levels (only 0.0625-0.1458, Table 2). Two populations from the Solimões landrace had the highest diversity, which would be consistent with the observation of Rodrigues et al. (2003) that Solimões has a higher heterozygosity than the Putumayo and Pará landraces, perhaps as the result of hybridisation between the Putumayo and Pará landraces.

Table 2 Gene diversity statistics within Peach palm populations along the Cuiparillo and Paranapura Rivers, Peru and samples from three other landraces in Peru and Brazil. $H_{j}$ Expected heterozygosity under Hardy-Weinberg genotypic proportions; Nei's gene diversity

\begin{tabular}{|c|c|c|c|c|}
\hline Population & $\begin{array}{l}\text { Number of } \\
\text { individuals analyzed }\end{array}$ & $\begin{array}{l}\text { Number of } \\
\text { polymorphic loci }{ }^{\mathrm{a}}\end{array}$ & $\begin{array}{l}\text { Proportion of } \\
\text { polymorphic loci }(\%)^{\mathrm{b}}\end{array}$ & $H_{\mathrm{j}}$ \\
\hline Col1 & 20 & 109 & 53.7 & 0.2462 \\
\hline $\mathrm{Col} 2$ & 18 & 110 & 54.2 & 0.2367 \\
\hline Col3 & 6 & 74 & 36.5 & 0.2278 \\
\hline Col4 & 14 & 108 & 53.2 & 0.2648 \\
\hline All samples along Cuiparillo River & 58 & 125 & 61.6 & 0.2439 \\
\hline Indi1 & 8 & 93 & 45.8 & 0.2620 \\
\hline Indi2 & 10 & 88 & 43.3 & 0.2464 \\
\hline Indi3 & 14 & 97 & 47.8 & 0.2345 \\
\hline Indi4 & 6 & 85 & 41.9 & 0.2539 \\
\hline Indi5 & 17 & 107 & 52.7 & 0.2572 \\
\hline Indi6 & 18 & 114 & 56.2 & 0.2609 \\
\hline Indi7 & 18 & 113 & 55.7 & 0.2572 \\
\hline Indi8 & 20 & 112 & 55.2 & 0.2433 \\
\hline Indi9 & 19 & 116 & 57.2 & 0.2709 \\
\hline Indi10 & 6 & 80 & 39.4 & 0.2512 \\
\hline Indi11 & 3 & 61 & 30.1 & 0.2510 \\
\hline Indi12 & 6 & 79 & 38.9 & 0.2350 \\
\hline All samples along Paranapura River & 145 & 133 & 65.5 & 0.2519 \\
\hline Pampa Hermosa landrace & 203 & 136 & 67.0 & 0.2499 \\
\hline Put 1 & 8 & 91 & 44.8 & 0.2366 \\
\hline Put2 & 5 & 73 & 36.0 & 0.2347 \\
\hline Sol3 & 4 & 59 & 29.1 & 0.2138 \\
\hline Sol4 & 5 & 77 & 38.0 & 0.2467 \\
\hline Sol5 & 6 & 85 & 41.9 & 0.2548 \\
\hline Par6 & 2 & 28 & 13.8 & 0.1458 \\
\hline Par7 & 5 & 41 & 20.2 & 0.1400 \\
\hline Par8 & 2 & 12 & 5.9 & 0.0625 \\
\hline All other landrace samples & 37 & 132 & 65.0 & 0.1918 \\
\hline All samples & 240 & 144 & 70.9 & 0.2306 \\
\hline
\end{tabular}

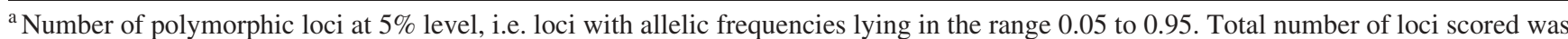
203

${ }^{\mathrm{b}}$ Proportion of polymorphic loci at the $5 \%$ level 
Table 3 Genetic differentiation among peach palm populations in Peru and Brazil. $H_{w}$ Mean gene diversity within populations (Nei's $H_{\mathrm{s}}$ ), $H_{t}$ total gene diversity, $N_{m}$ estimate of gene flow among populations

\begin{tabular}{|c|c|c|c|c|c|c|}
\hline Among populations within group & Between groups & $\begin{array}{l}\text { Number of } \\
\text { populations or groups }\end{array}$ & $H_{\mathrm{w}}$ & $H_{\mathrm{t}}$ & Nei's $G_{\mathrm{st}}$ & $N_{\mathrm{m}}^{\mathrm{a}}$ \\
\hline Colonist & & 4 & 0.2439 & 0.2534 & $0.0377 * *$ & 6.4 \\
\hline Indigenous & & 12 & 0.2519 & 0.2629 & $0.0416 * *$ & 5.8 \\
\hline Other landraces & & 8 & 0.1918 & 0.2964 & $0.3504 * *$ & - \\
\hline Colonist and indigenous & & 16 & 0.2499 & 0.2630 & $0.0497 * *$ & 4.8 \\
\hline \multirow[t]{4}{*}{ Colonist, indigenous and other landraces } & & 24 & 0.2306 & 0.2887 & $0.2013 * *$ & - \\
\hline & Colonist vs indigenous & 2 & 0.2573 & 0.2639 & $0.0249 * *$ & - \\
\hline & $\begin{array}{l}\text { Colonist vs indigenous vs } \\
\text { other landraces }\end{array}$ & 3 & 0.2676 & 0.2884 & $0.0720 * *$ & - \\
\hline & $\begin{array}{l}\text { Colonist and indigenous vs } \\
\text { other landraces }\end{array}$ & 2 & 0.2752 & 0.3005 & $0.0842 * *$ & - \\
\hline
\end{tabular}

\footnotetext{
${ }^{a}$ Assuming that $\mathrm{N}_{\mathrm{m}}=\left(1 / F_{\mathrm{st}}-1\right) / 4$ and calculated only for cases where it is reasonable to consider gene flow

Significance level: $* * P<0.01$
}

Genetic diversity and differentiation

The levels of genetic differentiation among populations $\left(G_{\mathrm{st}}\right)$ were low but significant (Table 3). Genetic differentiation among populations was slightly higher for the indigenous communities along the Paranapura River $\left(G_{\mathrm{st}}=0.0416\right)$ than for the colonist communities along the Cuiparillo River $\left(G_{\mathrm{st}}=0.0377\right.$, both are significantly different from zero, $P<0.01)$. Genetic differentiation among the other landrace populations $\left(G_{\mathrm{st}}=0.3504, \mathrm{P}<0.01\right)$ was notably greater than the differentiation among populations in the indigenous and colonist communities, consistent with the fact that these populations represent three different landraces.

Taking the populations along each river as a panmictic population, we can calculate the genetic differentiation between them as $G_{\mathrm{st}}=0.0249$, which is low but significantly different from zero $(P<0.01)$. Assuming that gene flow can be estimated from $F_{\text {st }}$ or $G_{\text {st }}$ values, while recognising that the assumptions necessary for this calculation are rarely met (Whitlock and McCauley 1999), these values correspond to considerable gene flow among populations: $N_{\mathrm{m}}=5.8$ for indigenous communities and 6.4 for colonist communities. When all these populations are considered as one group of populations, the estimated average gene flow among them was $N_{\mathrm{m}}=4.8$. This is in the same order of magnitude as the estimates of Rodrigues et al. (2003) in some of the Brazilian landraces.

Principal coordinate analysis

In a PCO with all samples (Fig. 2), the first two axes explained $5 \%$ and $3 \%$, respectively, of the variation in the matrix and differentiated the landrace samples from eastern and western Brazil from the populations managed by colonist and indigenous communities in Peru. There was extensive overlap between colonist and indigenous populations and the population from Iquitos in Peru (Put1). Analysis of only the plants from populations managed by colonist and indigenous communities in Peru showed that plants from indigenous populations were

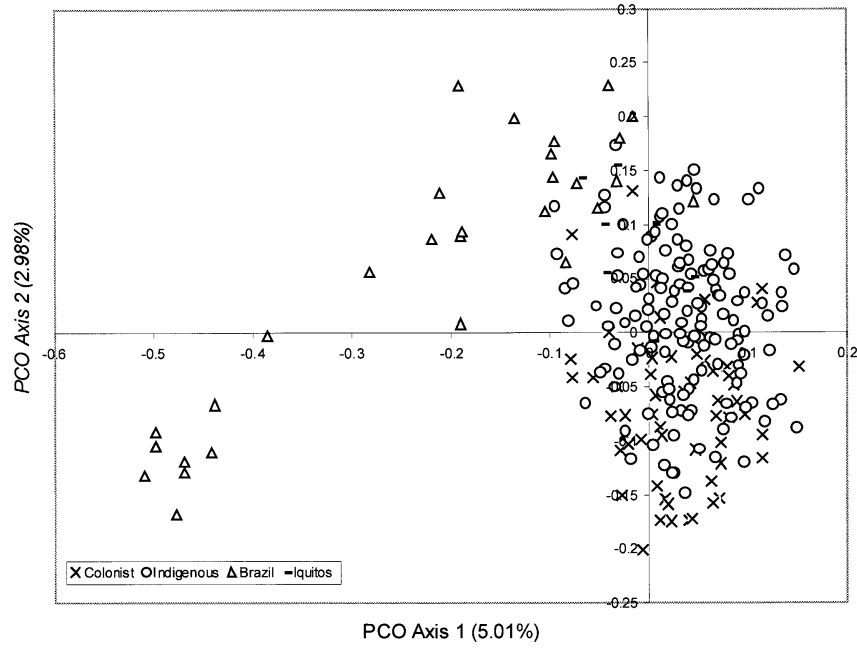

Fig. 2 Principal coordinate analysis of the AFLP profiles constructed using 144 polymorphic DNA fragments from all individual samples of the peach palm populations managed by colonist and indigenous communities in Peru, and other landraces in Peru and Brazil

slightly more diverse, but both groups largely overlapped and the plot explained only $6 \%$ of the variation (not shown).

\section{Cluster analysis}

Cluster analysis based on genetic distances (Fig. 3) revealed three major population clusters, which generally reflected the Pampa Hermosa landrace (Col and Indi samples), the Putumayo and Solimões landraces combined (Put and Sol) and the Pará landrace (Par). Populations of the Pampa Hermosa landrace managed by colonist communities and indigenous communities in Peru generally fell into one large group, with the colonist samples loosely attached. The Santa Rita population (Indi12) and the Putumayo population from Iquitos (Put1) clustered somewhat intermediate. For the populations along the two rivers bootstrap values were low, consistent 


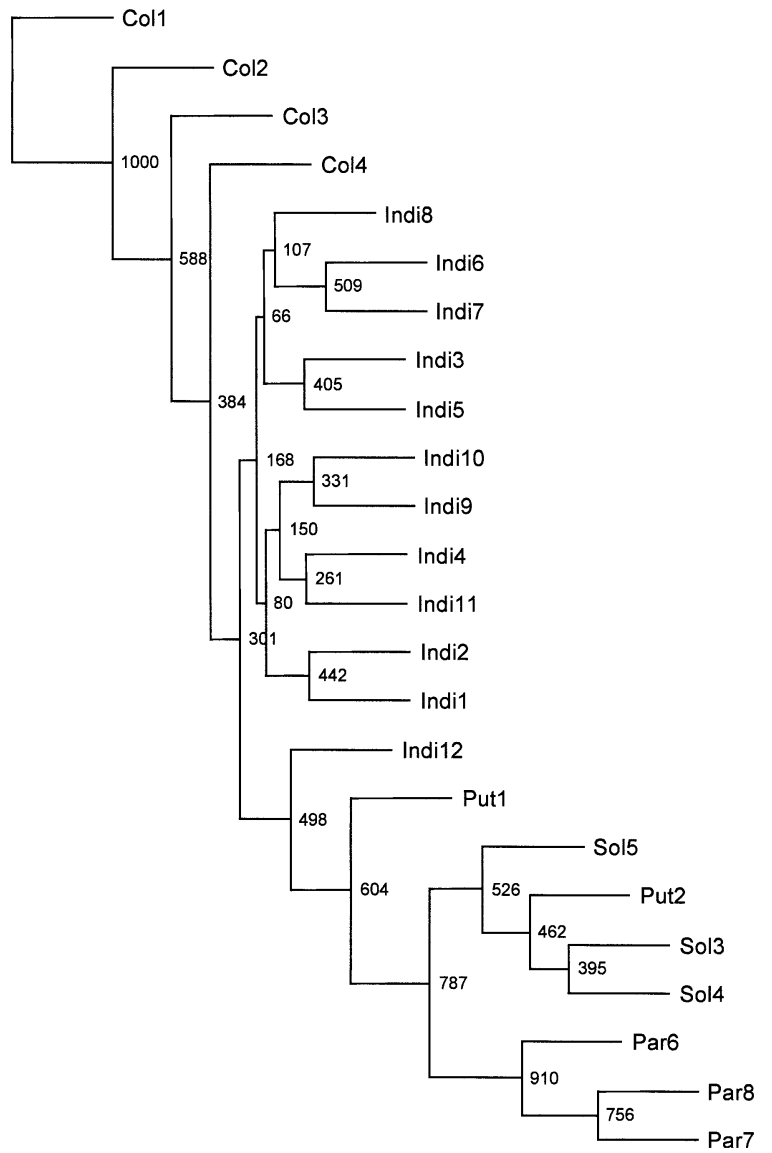

Fig. 3 Unrooted neighbour joining tree of Nei's genetic distance among populations of peach palm in colonist and indigenous communities in Peru, and other landraces in Peru and Brazil. Figures indicate bootstrap values (1,000 replications)

with the fact that only a small part of the diversity is partitioned between populations. The cluster of western landrace samples with Putumayo and Solimões landrace populations intermingled, supports the proposal by Sousa et al. (2001), Clement et al. (2002) and Rodrigues et al. (2003) that Solimões is part of the Putumayo landrace. The eastern cluster of Pará landrace populations is supported by high bootstrap values. This is consistent with the high pairwise $F_{\text {st }}$ values between them and all other samples (see Electronic Supplementary Material), and it indicates that these samples are quite different from the western landraces (cf. Rodrigues et al. 2003).

\section{Isolation by distance}

An isolation-by-distance relationship may exist among a more or less continuous series of populations that have a limited exchange of individuals with their neighbouring populations. The mean $N_{\mathrm{m}}$ of 4.8 for populations from the colonist and indigenous communities would be sufficient to keep populations from differentiating significantly. Nei's genetic distance between pairs of populations (see Electronic Supplementary Material) was smallest for the

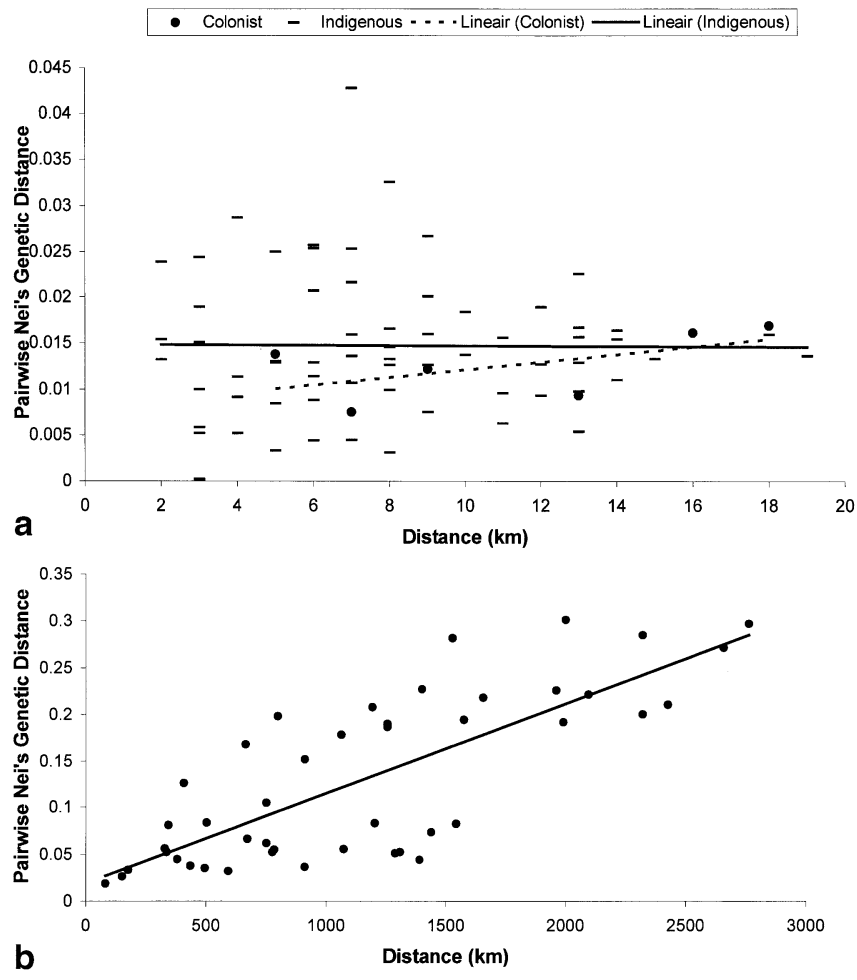

Fig. 4 a Absence of isolation-by-distance relationship among populations managed by indigenous communities along the Paranapura River and populations managed by colonist communities along the Cuiparillo River. Correlation between pairwise Nei's genetic distance and geographical distance, $R^{2}=0.0001$ and Mantel test of correlation, $P<0.4910$ for indigenous communities; $R^{2}=$ 0.2611 and $P<0.0890$ for colonist communities. b Isolation by distance among populations sampled across South America, $R^{2}=0.6016, P<0.0010$. In $\mathbf{b}$, only Coll and Indi1 were included, one population of each of the sampled rivers, for the Pampa Hermosa landrace

colonist communities along the Cuiparillo River (up to 0.017 ) and somewhat larger between some populations managed by indigenous communities along the Paranapura River (up to 0.043). These genetic distances are very low and often not significant, indicating considerable gene flow among these populations. When some of the other landraces were involved, pairwise $F_{\mathrm{st}} \mathrm{s}$ went up to 0.301 . Most of the genetic distances involving populations from other landraces were significant, provided the number of samples tested was not too low.

Since the Cuiparillo and Paranapura populations were at least $45 \mathrm{~km}$ apart, which is much more than the largest distance between populations within each of these river systems, we carried out the isolation-by-distance analysis separately among populations within the two river systems. The results (Fig. 4a) show that there was no effect of geographic distance on genetic distance for up to more than $20 \mathrm{~km}$ along each river. This suggests that genetic material has been exchanged regularly among communities along both rivers, but not specifically between adjacent villages. Rather, exchange took place over distances of more than $20 \mathrm{~km}$. A good candidate mech- 
anism would be trade at the markets in the major city in the vicinity, Yurimaguas, which is less than $50 \mathrm{~km}$ away from all populations, when measured as the crow flies.

For all samples across landraces, we do find a significant isolation-by-distance for up to $3,000 \mathrm{~km}$ (Fig. 4b). This is consistent with a regional exchange of genetic material between these populations, even though they are considered to be from different landraces.

\section{Discussion}

In this study, we compared genetic diversity in peach palm populations managed by either indigenous or colonist farming communities along the Paranapura and Cuiparillo rivers in Peru. A case study of farmers' use and management of tree germplasm in the Peruvian Amazon (Brodie et al. 1997) showed that farmers in an indigenous community maintained more species and more individuals per species in their secondary forests, compared with farmers in the colonist communities. In our study, genetic diversity within populations of peach palm was only slightly greater for the indigenous communities than for the colonist communities, and this could also be due to the larger sample size in the indigenous communities.

Genetic diversity within peach palm populations managed by the indigenous and colonist communities in Peru was slightly greater than diversity in the samples from other landraces from Peru and Brazil. Although the comparisons with landraces samples are confounded by differences in sample sizes, it does suggest that farming communities in the Peruvian Amazon are maintaining a relatively broad genetic base in their peach palm populations. We did not assess diversity in the undomesticated taxon, B. gasipaes var. chichagui. Undomesticated populations may have relatively greater diversity than domesticated populations (Ledig 1992). For example, in a study of SSR allelic diversity in Inga edulis Mart., another widely domesticated fruit-tree species in the Peruvian Amazon, domesticated populations on farms had lower genetic diversity than undomesticated populations in nearby primary forests (T. Pennington et al., unpublished data).

Most of the genetic variation in peach palm occurred within populations rather than among populations. Although the genetic differentiation among populations managed by the indigenous and colonist communities in Peru, i.e. among populations within the Paranapura and Cuiparillo rivers, was significant, it accounted for only about $5 \%$ of the variation. Similarly, the genetic differentiation between these two groups of populations accounted for only $2.5 \%$ of the variation. Even among the samples from the other landraces collected across the Amazon, genetic differentiation among populations accounted for only about $12 \%$ of the variation. Rodrigues et al. (2003) estimated genetic variation among a number of peach palm landraces using RAPDs and reported values close to $15 \%$. Rodrigues et al. (2003) also recalculated allozyme data from Clement et al. (1997) and found a nearly identical value. Relatively low genetic differentiation among populations and high within-population diversity also have been reported for undomesticated populations of Calycophyllum spruceanum Benth. using AFLPs (Russell et al. 1999), and for both domesticated and undomesticated populations of I. edulis Mart. using SSR (T. Pennington et al., unpublished data) in the Peruvian Amazon.

The results showed considerable gene flow among peach palm populations managed by the colonist and indigenous communities in Peru and also between these two groups of populations. Both pollen movement and natural seed dispersal (by birds and rodents) are thought to occur only across relatively short distances (100-200 m, Mora-Urpi et al. 1997). However, in their study of population structure in heart of palm (Euterpe edulis) in central Brazil, Gaiotto et al. (2003) found high levels of gene flow and up to 22-km pollination distance, despite that the main pollinator was thought to be a short-flyingdistance bee. To resolve this discrepancy, alternative pollinators (birds) were proposed, and a series of bird species appears to be potential seed dispersers. In the domesticate peach palm, we do not know the actual pollination distances. However, we do know that farmers and commercial traders are causing 'long-distance' gene flow through seeds. Within communities along the Paranapura and Cuiparillo rivers, Weber et al. (1997) observed considerable exchange of germplasm. Farmers collect seed from selected palms on their farms and on neighbouring farms and select fruits in the local markets for planting on their farms. In addition, farmers from communities along both rivers market most of their crop in Yurimaguas (see Fig. 1), which is a major commercial centre for the peach palm industry, either directly or indirectly through commercial traders. Farmers select desirable fruits/seeds in the Yurimaguas market and take them back to their farms for planting (Sotelo Montes et al., unpublished). Commercial traders from Yurimaguas distribute fruits/seeds to other regions in the Amazon and elsewhere in Latin America where demand exists for fruit or heart-of-palm plantations. Such regional trade is consistent with the absence of isolation-by-distance along a stretch of $20-\mathrm{km}$ river (Fig. 4). It will result in immigration of propagules from several different source populations into local populations, resembling the 'migrant pool model' of immigration which leads to additional gene flow reducing population differentiation (Giles and Goudet 1997). Trade with other regions in the Amazon region is also consistent with the isolationby-distance structure found among the landraces that were included in this study.

The clear genetic differentiation among three of the peach palm landraces in this study is consistent with Mora-Urpí et al. (1993), who noted that there is considerable genetic variation in morphological traits among the landraces. In our study, cluster analysis generally grouped the populations based on their landrace classification: the Pampa Hermosa landrace (colonist and indigenous communities in Peru), the samples from western Brazil in 
intermediate position, regardless of whether they are classified as Putamayo or Solimões landrace and, clearly separate, the samples from the Pará landrace from eastern Brazil. As Benjamin Constant is essentially the type locality of the Putumayo landrace, the western grouping is consistent with them being either Putamayo landrace or hybrids (Sousa et al. 2001; Clement et al. 2002; Rodrigues et al. 2003). The intermediate position of Iquitos (Put1) between Pampa Hermosa and Putumayo samples in Fig. 3 supports Mora-Urpí and Clement's (1988) classification of Iquitos as a hybrid population, with morphogenetic variation from the Putumayo, Pampa Hermosa and Tigre landraces and possibly from other landraces and wild populations in Peru. Nevertheless, the isolation-by-distance study (Fig. 4b) is consistent with some exchange of material between landraces. As a consequence, even if such units would be morphologically stable due to continuous selection, the genetic diversity in neutral markers may change gradually.

Implications for genetic resource management with farming communities

Strategies for genetic resource management should be based on the genetic structure of the populations. Results of this study suggest three features of the genetic structure of peach palm in Peru: (1) most of the genetic diversity occurs within rather than among the domesticated populations, and current management practices have not led to a considerable loss of diversity; (2) genetic differentiation between groups of populations managed by communities from different river systems is low but significant; and (3) genetic differentiation among individual populations managed by communities within these river systems is even lower but still significant. Management strategies, therefore, should attempt to conserve the diversity at all three levels within each landrace, but also keep in mind that a landrace is not a fixed genetic unit, but resembles a metapopulation in which drift and selection in farmers' fields are counterbalanced by trafficking of genetic material (Louette 2000). From a practical point of view, a conservation-through-use approach, in which farming communities are empowered to both use and conserve their genetic resources, would match very well the current practice. It may be more effective than traditional in situ or ex situ approaches for domesticated species (O'Neill et al. 2001; Weber et al. 2001). Considering the genetic structure of peach palm populations as revealed in this study, the approach would involve working with several, geographically discrete farming communities located in different river systems within different regions of the Peruvian Amazon. Regions would be selected to capture diversity among landraces. Within each region/landrace, several farming communities from different river systems should be involved, because subdivided populations retain variation better than a single panmictic population. In each river system, a few phenotypically diverse populations in different com- munities could be identified with farmers and targeted for management. Community-based seed collections could be coordinated for each population, and then the seeds could be mixed together and distributed for establishing new plantations in the community or for sale to seed traders. We recommend at least 30 (but preferably 50, Brown and Marshall 1995) different mother trees in each population for collection. As the pollination distances are not known, usually a minimum distance of at least $100 \mathrm{~m}$ between each mother tree is used in such collections. For the two rivers studied here in detail, data on significance of genetic differences between populations (see bolded figures in Electronic Supplementary Material) could be used to select those populations that merit separate conservation at that level.

The in situ conservation efforts may be complemented by participatory research in the farming communities to identify superior germplasm in terms of both adaptive traits (e.g. drought, pest and insect resistance) and economic traits (e.g. fruit quality and quantity), to optimise the 'selection' process that is also inherent to the usage of landraces. In this process, selection for improved production has to be balanced with maintenance of genetic diversity. One important piece of information for this is the actual pollen dispersal distance (which determines the size of the open-pollinated maternal families). The current development of microsatellite markers for peach palm will allow establishing this in the near future.

Acknowledgements We thank personnel from the International Centre for Research in Agroforestry in Yurimaguas and Pucallpa, Peru for conducting the fieldwork in this study and providing additional information necessary for the realisation of this study. We also thank Dr. Charles R. Clement, INPA and Paul Arens for providing useful comments on an earlier draft of this manuscript.

\section{References}

Ajmone-Marsan P, Negrini R, Milanesi E, Bozzi R, Nijman IJ, Buntjer JB, Valentini A, Lenstra JA (2002) Genetic distance within and across cattle breeds as indicated by biallelic AFLP markers. Anim Genet 33:280-286

Arens P, Coops H, Jansen J, Vosman B (1998) Molecular genetic analysis of black poplar (Populus nigra L.) along Dutch rivers. Mol Ecol 7:11-18

Bohonak AJ (2002) IBD (Isolation By Distance): a program for analyses of isolation by distance. J Hered 93:153-154

Brodie AW, Labarta Chávarri RA, Weber JC (1997) Tree germplasm management and use on-farm in the Peruvian Amazon: a case study from the Ucayali region, Peru. Research report, Overseas Development Institute, London and International Centre for Research in Agroforestry, Nairobi, Kenya

Brown AHD, Marshall DR (1995) A basic sampling strategy: theory and practice. In: Guarino L, Rasmanatha Rao V, Reid R (eds) Collecting plant genetic diversity - technical guidelines. CAB International, Wallingford, UK, pp 75-91

Clement CR (1988) Domestication of the pejibaye palm (Bactris gasipaes): past and present. Adv Econ Bot 6:155-174

Clement CR (1990) Regeneração natural de pupunha (Bactris gasipaes). Acta Amazonica 20:399-403 
Clement CR, Arkcoll DB (1984) Observações sobre autocompatibilidade em pupunha (Bactris gasipaes H.B.K., Palmae). Acta Amazonica 14:337-342

Clement CR, Mora-Urpí J (1987) Pejibaye palm (Bactris gasipaes, Arecaceae): multi-use potential for the lowland humid tropics. Econ Bot 41: 302-311

Clement CR, Aradhya MK, Manshardt MR (1997) Allozyme variation in spineless pejibaye (Bactris gasipaes Palmae). Econ Bot 51:149-157

Clement CR, Reis Sousa N, Picanço Rodriques D, Astolfí Filho S, Núñez Moreno Y, Torres Pascual V, Gallego Rodríguez FJ (2002) Use of AFLPs to distinguish landraces of pejibaje (Bactris gasipaes) in Brazilian Amazonia. Sci Agric 59:749753

Felsenstein J (1989) PHYLIP-Phylogeny Inference Package, version 3.2. Cladistics 5:164-166

Fulton E, Chunwongse J, Tanksley SD (1995) Microprep protocol for extraction of DNA from tomato and other herbaceous plants. Plant Mol Biol Rep 13:207-209

Gaiotto FA, Grattapaglia D, Vencovsky R (2003) Genetic structure, mating system, and long-distance gene flow in heart of palm (Euterpe edulis Mart.). J Hered 94:399-406

Giles BE, Goudet J (1997) A case study of genetic structure in a plant metapopulation. In: Hanski IA, Gilpin ME (eds) Metapopulation biology: ecology, genetics, and evolution. Academic Press, San Diego, pp 429-454

Iriarte Martel JH, Ferraudo AS, Môro JR, Perecin D (2003) Estatística multivariada na discriminação de raças amazônicas de pupunheiras (Bactris gasipaes Kunth) em Manaus (Brasil). Rev Bras Fruticult 25:115-118

Ledig FT (1992) Human impacts on genetic diversity in forest ecosystems. Oikos 63:87-108

Louette D (2000) Traditional management of seed and genetic diversity: what is a landrace? In: Brush SB (ed) Genes in the field: On-farm conservation of crop diversity. Lewis, Boca Raton, Fla., pp 109-142

Lynch M, Milligan BG (1994) Analysis of population genetic structure with RAPD markers. Mol Ecol 3: 91-99

Miranda IP de A, Clement CR (1990) Germinación y almacenamiento del polen de pejibaye (Bactris gasipaes H.B.K., Palmae). Rev Biol Trop 38:29-33

Mora-Urpí J, Clement CR (1988) Races and populations of peach palm found in the Amazon basin. In: Clement CR, Coradin L (eds) Final report (revised): peach palm (Bactris gasipaes) germplasm bank. US-AID project report. INPA/CENARGEN, Manaus, Brazil, pp 78-94

Mora-Urpí J, Echeverría JG (1999) Palmito de pejibaye (Bactris gasipaes Kunth): su cultivo e industrialización. Imprensa de la Universidad de Costa Rica, San José, Costa Rica

Mora-Urpí J, Solís E (1980) Polinización en Bactris gasipaes H.B.K. Palmae. Rev Biol Trop 28:153-174

Mora-Urpí J, Clement CR, Patiño JM (1993) Diversidad genética en pejibaye. I. Razas y poblaciones híbridas. In: Mora-Urpí J, Szott LT, Murillo M, Patiño VM (eds) IV Congreso Internacional sobre Biología, Agronomía e Industrialización del Pijuayo. Editorial de la Universidad de Costa Rica, San José, Costa Rica, pp 11-19
Mora-Urpí J, Weber JC, Clement CR (1997) Peach palm (Bactris gasipaes Kunth). Promoting the conservation and use of underutilized and neglected crops. 20. Institute of Plant Genetics and Crop Plant Research, Gatersleben/International Plant Genetics Resources Institute, Rome, Italy. http://www.ipgri.cgiar. org/publications/pdf/155.pdf

O'Neill GA, Dawson IK, Sotelo Montes C, Guarino L, Current D, Guariguata M, Weber JC (2001) Strategies for genetic conservation of trees in the Peruvian Amazon basin. Biodivers Conserv 10:837-850

Rodrigues DP, Astolfí Filho S, Clement CR (2003) Molecular marker-mediated validation of morphologically defined landraces of pejibaje (Bactris gasipaes) and their phylogenetic relationships. Genet Resour Crop Evol (in press)

Rojas-Vargas S, Ramírez P, Mora Urpí J (1999) Polimorfismo isoenzimático en cuatro razas y un híbrido de Bactris gasipaes (Palmae). Rev Biol Trop 47:755-761

Russell JR, Weber JC, Booth A, Powell W, Sotelo Montes C, Dawson IK (1999) Genetic variation of riverine populations of Calycophyllum spruceanum in the Peruvian Amazon Basin, revealed by AFLP analysis. Mol Ecol 8:199-204

Savelkoul PHM, Aarts HJM, Dijkshoorn L, Duims B, De Haas J, Otsen M, Schouls L, Lenstra JA (1999) Amplified fragment length polymorphism (AFLP), the state of an art. J Clin Microbiol 37:3083-3091

Sotelo Montes C, Weber JC (1997) Priorización de especies arbóreas para sistemas agroforestales en la selva baja del Perú. Agrofor Am 4(14):12-17

Sousa NR, Rodrigues DP, Clement CR, Nagao EO, Astolfi-Filho S (2001) Discriminação de raças primitivas de pupunha (Bactris gasipaes) na Amazônia brasileira por meio de marcadores moleculares (RAPDs). Acta Amazonica 31:539-545

Tanksley SD, McCouch SR (1997) Seed banks and molecular maps: unlocking genetic potential from the wild. Science 227:1063-1066

Vekemans X, Beauwens T, Lemaire M, Roldan-Ruiz I (2002) Data from amplified fragment length polymorphism (AFLP) markers show indication of size homoplasy and of a relationship between degree of homoplasy and fragment size. Mol Ecol $11: 139-151$

Villachica HL (1996) Cultivo del Pijuayo (Bactris gasipaes Kunth) para Palmito en la Amazonía. Secretaria Pro-Tempore, Tratado de Cooperación Amazónica, No. 43, Lima, Perú

Vos P, Hogers R, Bleeker M, Reijans M, Van de Lee T, Hornes M, Frijters A, Pot J, Peleman J, Kuiper M, Zabeau M (1995) AFLP: a new technique for DNA fingerprinting. Nucleic Acids Res 23:4407-4414

Weber JC, Labarta Chávarri RL, Sotelo Montes C, Brodie AW, Cromwell E, Schreckenberg K, Simons AJ (1997) Farmers use and management of tree germplasm: case studies from the Peruvian Amazon Basin. In: Simons AJ, Kindt R, Place F (eds) Proceedings of an International Workshop on Policy Aspects of Tree Germplasm Demand and Supply. International Centre for Research in Agroforestry, Nairobi, Kenya, pp 57-63

Weber JC, Sotelo Montes C, Vidaurre H, Dawson IK, Simons AJ (2001) Participatory domestication of agroforestry trees: an example from the Peruvian Amazon. Dev Pract 11:425-433

Whitlock MC, McCauley DE (1999) Indirect measures of gene flow and migration: $F_{\text {st }} \neq 1 /(4 N m+1)$. Heredity $82: 117-125$ 